\title{
Indigenous paradiplomacy and the Orokawe hydroelectric dam on the Kunene River
}

\author{
Richard Meissner, Jeroen Warner
}

\begin{abstract}
What role can non-diplomats play in managing and altering power relations in transboundary river basins? We answer this by investigating the lobbying efforts of indigenous peoples to stop the construction of the planned Orokawe (Baynes) dam on the Kunene River. The Kunene River forms part of the border between Angola and Namibia with several concluded treaties in place. These treaties set the context of bilateral state diplomacy concerning the allocation and management of a transboundary water resource. The theoretical foundation of our investigation are ideational power conceptualizations and practice theory. We discuss the employment of ideational power in transboundary rivers with numerous practices, such as lobbying and transnational network development. This article argues that actors consciously practice power during transboundary water diplomacy.
\end{abstract}

Keywords: ideational power, Namibia, OvaHimba, OvaZemba, paradiplomacy, transboundary river basin

While joint dam projects have been hailed by their champions as symbols of regional integration, large dams on transboundary rivers have often created major inter- and transnational tensions or conflicts; they tend to displace people, often without proper compensation, affect environmental values in a major way, and alter the river flow with (feared) downstream effects. Moreover, so-called sunk costs, such as expensive technical feasibility studies, raise the investment stakes such that dam projects can become almost unstoppable, especially when governments argue the "absolute need" of such projects in the face of energy or water scarcities.

Such dam conflicts are often multilevel, causing tensions between upstream and downstream states but also between the dam-building state and affected indigenous or communal interest groups. These groups have learned to marshal domestic and international interest groups, social and environmental action groups, and corruption watchdogs (Meissner, 2016) 
to persuade states not to construct such infrastructure. In the 1990s, several hydropower projects around the world became controversial partly because of interest groups resisting their construction, including the Narmada in India, Arun in Nepal, the Lesotho Highlands Project, China's Three Gorges dam, and the Greater Anatolia Project multi-dam project in Turkey (Warner, 2004). Margaret Sikkink and Kathryn Keck (1998) have coined the concept "boomerang" to describe how governments refusing to respond to communal interest group protests and related activities were defeated by the massive international attention, which in several cases, led to investors withdrawing from these projects.

In this article, we ask what role can non-diplomats play in altering power relations in transboundary river basins? The present article's setting is the planned Orokawe (Baynes) dam on the Kunene River, shared by Angola and Namibia (Figure 1 and Figure 2). That said, how do nondiplomats, and particularly indigenous peoples, manage their interna-

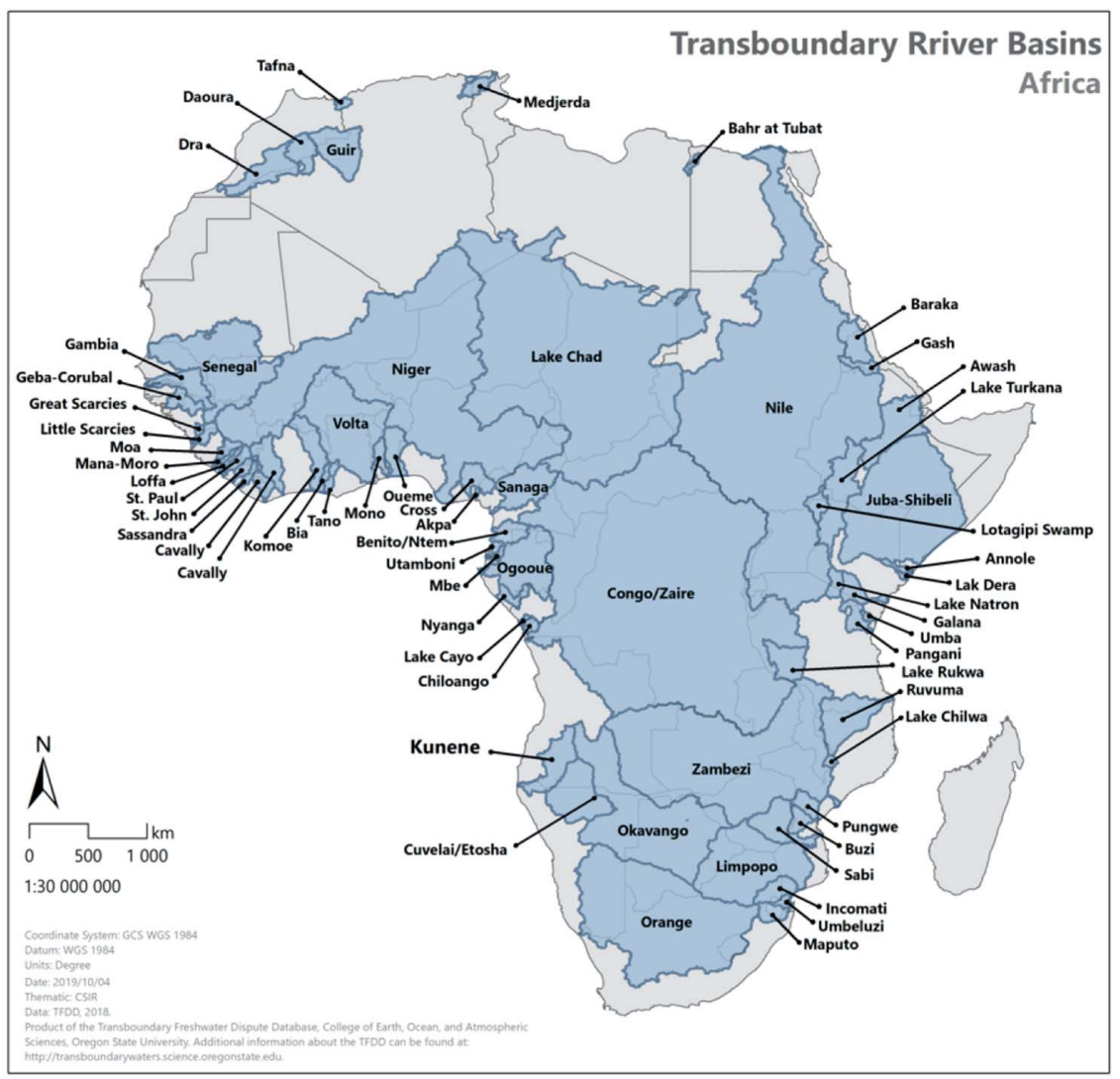

Figure 1 - Africa's shared river basins, highlighting the Kunene River (Map produced by Chris Paola) 

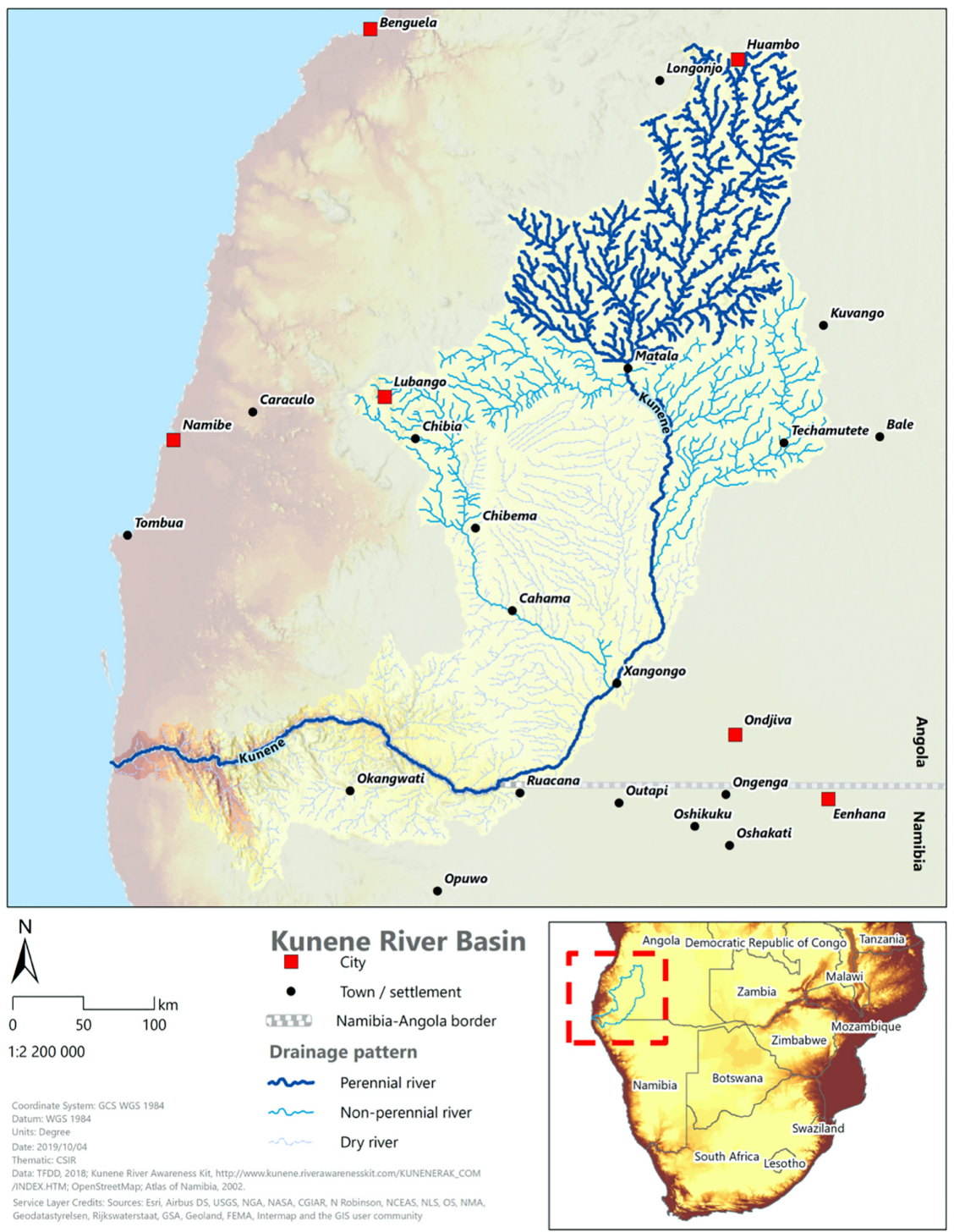

Figure 2 - Detailed map of the Kunene River basin

Data collection

tional environment to bring about change or to maintain the status quo in the Kunene River basin?

We will argue that in the process of indigenous paradiplomacy, actors consciously practice power in the course of diplomacy and that power manifests during certain activities in a transboundary diplomacy context. We examine and discuss a number of these activities that revolve around 
indigenous paradiplomacy regarding the Orokawe dam. To reach this goal, we structure the article as follows. In the first section, we present a literature review on the various meanings of diplomacy to position the article among existing scholarship and discuss the concepts of ideational power and practice theory. We then outline our methodology before investigating and analyzing indigenous paradiplomacy and diplomacy centered on the planned hydropower installation. This exercise will sketch the background and discursive strategy employed to exercise ideational power. We follow this with a discussion and a conclusion.

The Internet has become a valuable source for interest groups to publish their lobbying campaigns. This practice eases the identification of information for researchers who investigate the knowledge content of lobbying efforts. We turned to the internet to identify and download information on interest groups lobbying against the Orokawe dam. The primary website we used is administered by Earth Peoples. ${ }^{1}$ Earth Peoples is an international interest group, referring to themselves as "a global circle of indigenous peoples-grandmothers, grandfathers, mothers, fathers, youth, leaders, activists, educators, community members, world citizens, networks and organizations, working together to promote natural and human rights" (Earth Peoples, 2018). The purpose of the group is to "assist in the empowerment of earth peoples as informed decision makers" (Earth Peoples, 2018). Earth Peoples assisted the Kaokoland indigenous peoples in drafting the three declarations and filed complaint procedures to the United Nations.

Rebecca Sommer, a New York-based, German-born international human rights advocate and Earth Peoples' representative, posted the signed declarations on the interest group's blog in February 2012 (Earth Peoples, 2012). The declarations also have tags that take the reader to a webpage entitled: "German GIZ directly engaged with dispossessing indigenous peoples of their lands and territories in Namibia". On this page, Earth Peoples makes the argument that Germany's involvement in Namibia's land reform program through GIZ (Deutsche Gesellschaft für Internationale Zusammenarbeit) is "highly inappropriate." This webpage contains a narrative of the history of German colonization of Namibia in order to, among other reasons, exploit the latter's mineral wealth. Earth Peoples (2013) argues that the Namibian government does not recognize the traditional authority of the OvaHimba and OvaZemba traditional leaders. The webpage also contains links to YouTube videos, also produced by Sommer (SommerFilms, 2019). In the videos, OvaHimba leaders explain their problem of non-recognition by the Namibian government. The webpage furthermore holds information about the protests by the OvaHimba and OvaZemba when their members marched, in March 2013 in Opuwo, against the Orokawe dam and human rights violations. 
Since the blog can be accessed via the Internet from anywhere, its potential audience is global, but the lobbying campaign specifically targets the German government, particularly the German developmental agency GIZ, and the Namibian government. The postings on Earth Peoples' blog raised awareness of the plight of the two tribes and the difficulties they face in Namibian society. It is unclear how many people have visited the website since 2012 because we do not have access to the website's statistics. ${ }^{2}$

Using the website, we sourced three declarations that embody the indigenous paradiplomacy efforts of the indigenous peoples. The first is the Declaration of the most and directly affected OvaHimba, OvaTwa, OvaTjimba, OvaZemba against the Orokawe dam in the Baynes Mountains ${ }^{3}$ (Declaration, 2012b). The second declaration is entitled Declaration of the Zemba people of Namibia (Declaration, 2012c), while the third is a Declaration by the traditional leaders of Kaokoland in Namibia (Declaration, 2012a).

The first declaration (hereafter the Orokawe Declaration) is a document by all the indigenous peoples of the area where Angola and Namibia are planning to build the dam and is specifically aimed at declaring the people's resistance to it. The second statement (hereafter the OvaZemba Declaration) is from the OvaZemba and deals with various matters, such as indigenous rights, schooling for the OvaZemba, and the recognition of their traditional leadership structures as well as the OvaZemba's resistance toward the dam. The third declaration is from the OvaHimba (hereafter: the OvaHimba Declaration), and just like the OvaZemba Declaration, deals with matters affecting the OvaHimba, such as land rights, the recognition of their leadership structures by the Namibian government, and the dam. We analyzed these documents in the context of their ideational power.

\section{Definition of key terms}

Diplomacy is commonly thought as practices, laws, and customs in state institutions. Before the world became "Westphalian" after the peace treaty of 1648, commonly held to enshrine the nation-state model, religious authorities, knights, and parastatals exercised diplomacy. In recent times, non-state, sub-state, and transnational actors increasingly reappear in diplomacy. If we see diplomacy as "communication among different social groups and political entities," the practice does not have to be an exclusive attribute of nation-states (Cornago, 2010) and not only have to happen through nation-state diplomatic channels and lobbies. Paradiplomacy, or parallel diplomacy, is participation in international relations by noncentral 
governments through the establishment of permanent or ad hoc contacts with foreign public or private entities for the purpose of promoting various socioeconomic or cultural issues (Cornago, 2010). We consider this type of diplomacy as a counterweight to centralist modernizing states. Paradiplomacy emphasizes noncentral government entities, like provinces and municipalities and, therefore, does not cover non-state entities like communal interest groups and individuals (Nganje, 2014).

Actors not commonly considered sovereign but seeing themselves as representatives of political entities practice "indigenous paradiplomacy" (Aranda \& Salinas, 2017). Indigenous paradiplomacy should not be confused, however, with water diplomacy. Water diplomacy as outlined by Shafiqul Islam and Amanda Repella (2015) revolves around managing water resources in the face of complex problems. From these definitions, we see that the practice of "managing" is central to diplomacy paradigms. In this article, we are interested in the practices or activities underpinning indigenous paradiplomacy, which we define as non-state actors managing the relations among themselves, other non-state entities, and states located in the international environment considering possible (disruptive) changes facing indigenous peoples.

The Orokawe dam has been hailed by its proponents as an example of cooperation between Angola and Namibia that will generate much needed reliable and clean electricity to both countries (NamPower, 2018). However, for over two decades, indigenous peoples in Namibia, most notably the OvaHimba, have been resisting plans to build more dams on the Kunene, mobilizing domestic and international allies to make their point (Meissner, 2016). Meissner (2016) described the transnational nature of the resistance by the indigenous peoples in the Kunene River basin that centered around the proposed Epupa dam during the 1990s and early 2000s. The OvaHimba were assisted by several interest groups from Germany, Namibia, South Africa, and the United States in their efforts to raise awareness of their plight should Namibia construct the dam. During this time, the Angolan government was unenthusiastic to cooperate with Namibia on the dam since it was reconstructing other civil war-damaged dams in the upper reaches of the Kunene (Meissner, 2016).

As alluded to, diplomacy is "power in practice" (Adler-Nissen \& Pouliot, 2014) - a combination of "soft power" and more or less explicit "hard power." But how does this soft power work? For this, we need to study the practices of indigenous paradiplomacy, not only what formal diplomats do but also how others try to influence them, along with the frames they use.

In an earlier exposé of ideational power in transboundary river basins, Ana Elisa Cascão and Mark Zeitoun (2010) framed ideational power 
as the power over ideas represented as riparian states' capacity to impose and legitimize specific ideas and narratives. They used the concept "ideational power" in a specific state-centric ontology when they wrote: "In sum, ideational power allows the basin hegemon to control the perceptions of the allocative configuration of the societies both in its own country and in the neighboring riparian countries, thereby reinforcing its legitimacy" (Cascão \& Zeitoun, 2010, p. 29). Analyzing ideational power as the power that only states and/or hegemons in and of transboundary river basins hold is limiting. This ontology only advances knowledge in transboundary river basins consisting of states as the legitimate hydropolitical actors. Other actors, including non-state collectivities and individuals, could also wield this type of power that they could impose over riparian states and transboundary river basin hegemons. To explore this possibility, we need to move away from theoretical advances that give states, hegemons, and state-formed international organizations a privileged position in governance contexts to views of transboundary river realities that are more complex. This article will take such a view of a transboundary reality in a synergistic relationship between paradigms, theoretical models, and non-state and state policy practices. To progress a polycentric transboundary actor view, we, firstly, need to expand our understanding of ideational power and, secondly, present a theory that is epistemologically aligned to such an expanded sense of ideational power.

\section{Ideational powers}

To increase our understanding of ideational power, we will not talk of ideational power but ideational powers as expressed by Martin Carstensen and Vivien Schmidt (2016). For them, ideational power is "the capacity of actors (whether individual or collective) to influence other actors' normative and cognitive beliefs through the use of ideational elements" (Carstensen \& Schmidt, 2016, p. 321). The practice or activity of exercising ideational power "may occur directly through persuasion or imposition or indirectly by influencing the ideational context that defines the range of possibilities of others" (Carstensen \& Schmidt, 2016, p. 321). Seeing ideational power in this sense brings to the fore not only a plurality of actors but also a surfeit of affects that ideational power's imposition could have on others. Human rights norms, which is a central feature of the indigenous people's mobilization against the Orokawe dam, are normative elements of legitimate statehood and not just state action (Reus-Smit, 2001). Even so, ideational power relates not only to normative beliefs but also to 
cognitive principles. For Carstensen and Schmidt (2016), normative beliefs are the values communities hold, while cognitive beliefs are technical and scientific arguments.

Such a conceptualization of ideational powers can have far reaching implications not only for how we use paradigms and theories but also how researchers assist practitioners in formulating and implementing policies. The theory-practice nexus could find specific expression in the exercise of ideational powers linked to actors' contexts and how they operate in such situations, including the biophysical environment, in explaining their roles in indigenous paradiplomacy. When indigenous peoples invoke their human rights within transboundary river basins, a normative and invisible characteristic gets added to the biophysical environment's seemingly technical and scientific features. This view of transboundary river basins and the politics within them will come to the fore during our discussion. For now, we will summarily present the characteristics of three types of ideational power as presented by Carstensen and Schmidt (2016) (Table 1).

\section{Research design}

The Kunene River (Cunene in Angola) has its origin in an area of Angola where rainfall is in the region of 1500 millimeters per annum, resulting in the river having an annual flow of about 15 cubic kilometers per year $\left(\mathrm{km}^{3} / \mathrm{yr}^{-1}\right)$. The river forms a 340-kilometer border between Angola and Namibia. That the Kunene contains $15 \mathrm{~km}^{3} / \mathrm{yr}^{-1}$ is not the only unique biophysical feature; the river also has a steep gradient. From Ruacana to the Atlantic Ocean, 340 kilometers, the Kunene drops from an altitude of 1,100 meters above sea-level to mean sea-level. A number of cataracts or waterfalls are also present along the entire river course (Heyns, 2003) making the river suitable for hydroelectric generation (Meissner, 2016).

The Kunene's unique topographical character afforded the governors of Angola and Namibia an important source of water to populated areas and hydroelectric generation (Heyns, 2003). Angola is often labeled a "sleeping giant" - once it wakes up for real and develops it resources, Namibia as a downstreamer with far poorer water resources could be seriously affected. A series of hydroelectric projects was planned, including Ruacana, Epupa, Calueque, and Orokawe. Hence it has been in Namibia's interest to develop a positive, hydro-diplomatic relationship with its neighbor. Angola and Namibia, however, have not yet established any joint management structure for the Kunene, there is only a Permanent Joint Technical Commission. 


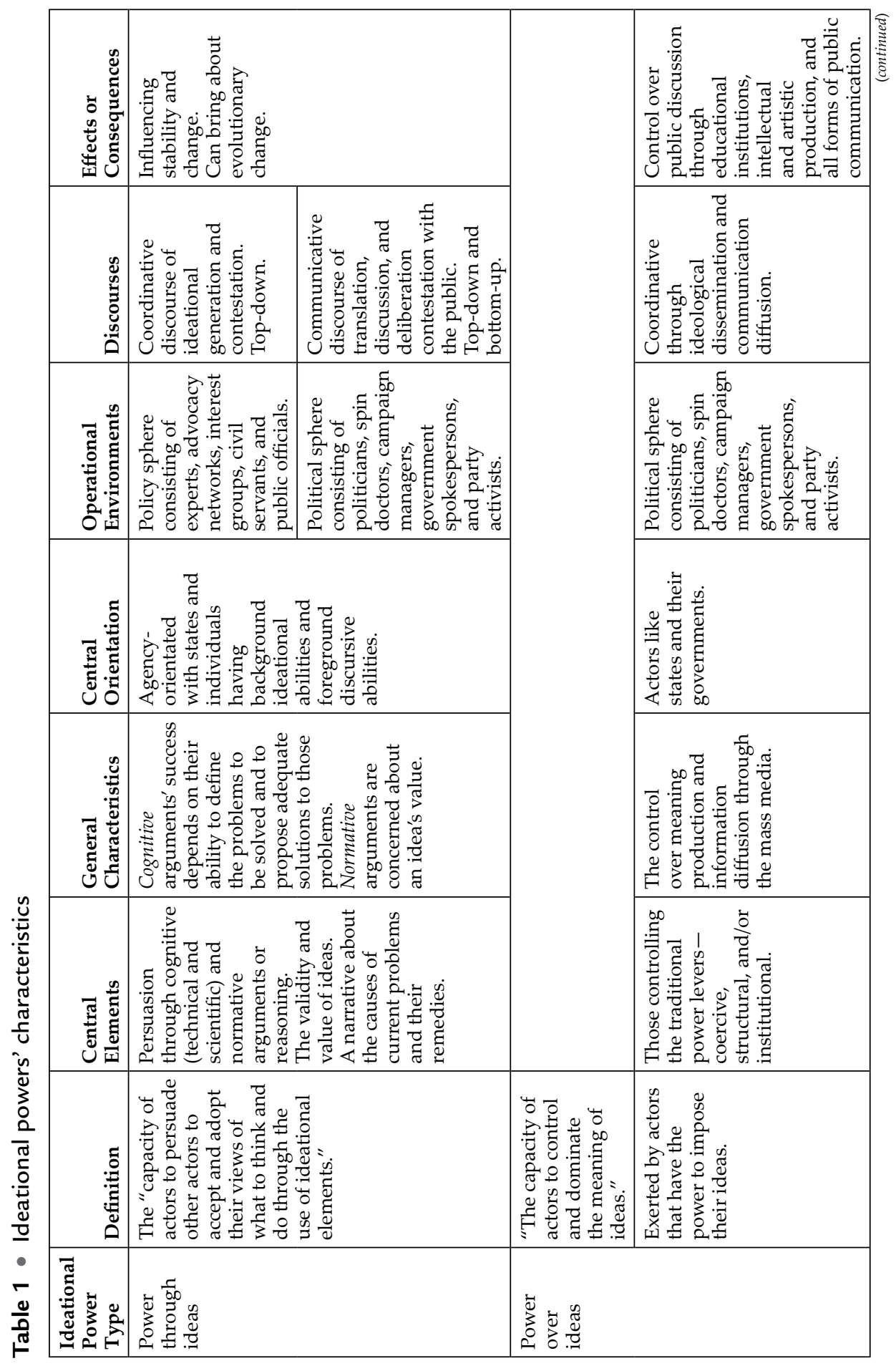




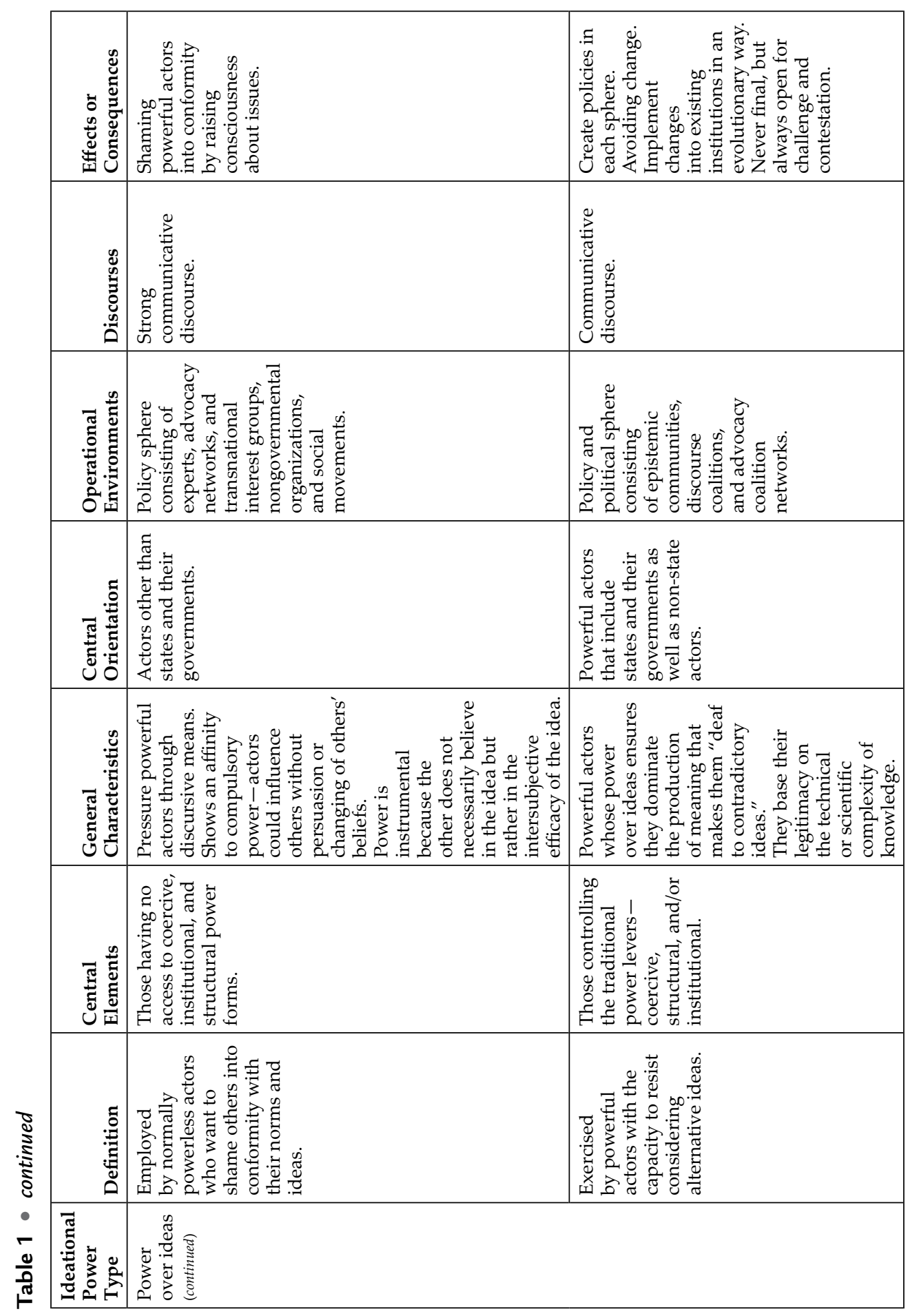




\begin{tabular}{|c|c|}
\hline 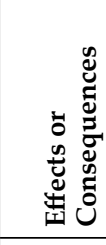 & 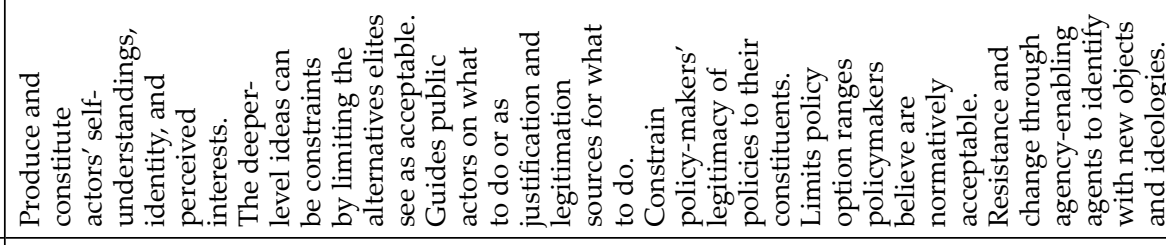 \\
\hline 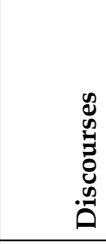 & 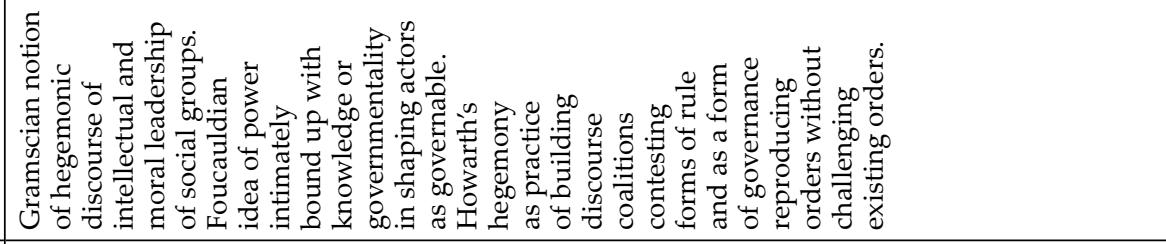 \\
\hline 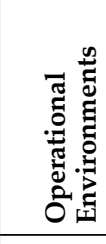 & 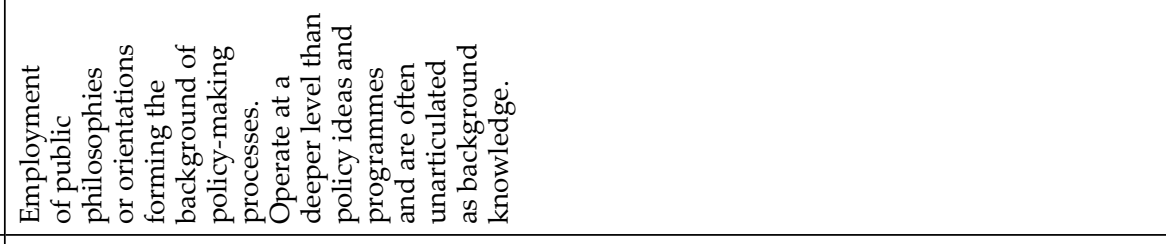 \\
\hline 焉 & 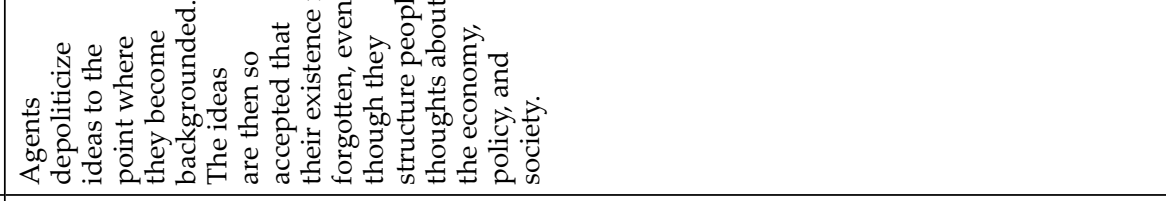 \\
\hline 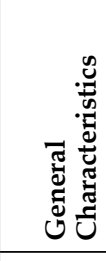 & 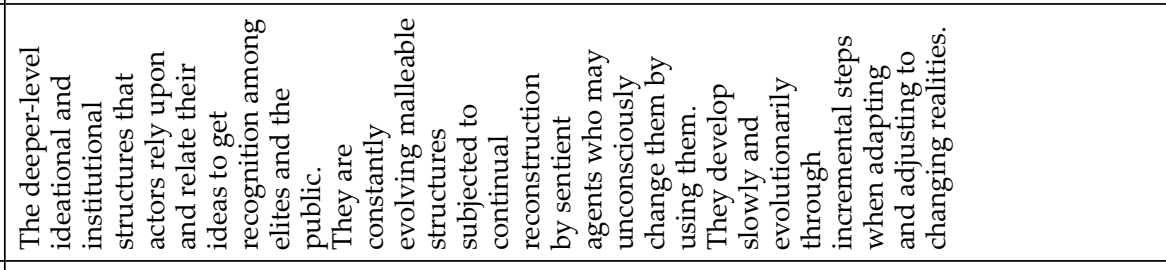 \\
\hline 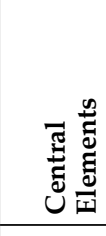 & 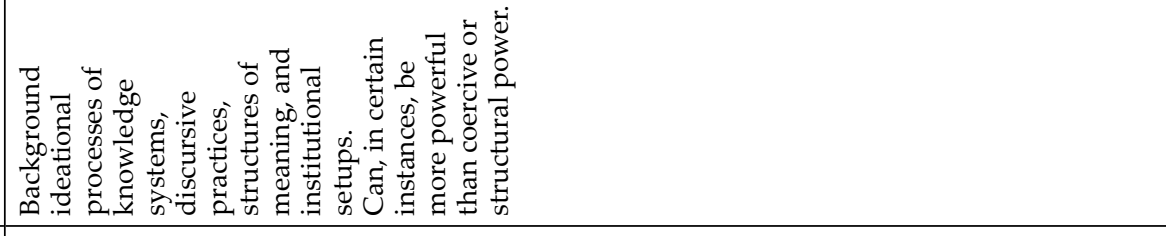 \\
\hline 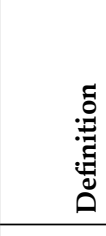 & 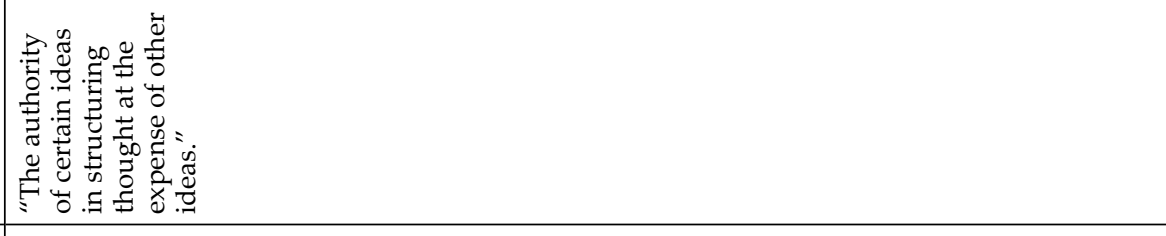 \\
\hline 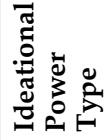 & 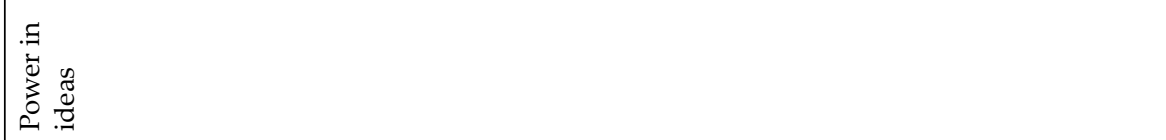 \\
\hline
\end{tabular}


The Orokawe dam was hatched in 1964, but in the 1970s and 1980s, violent conflict intervened, both the Angolan Civil War and the struggle for decolonization of Namibia, for which Angola allowed its territory as a shelter for the South West Africa People's Organization (SWAPO) resistance movement, which, after independence became Namibia's ruling party (Meissner, 2016). Although the subsequent analysis in this article will mostly focus on Angola-Namibian relations, the geostrategic nature of the Kunene region brings South Africa into the picture. It is worth mentioning that post-apartheid, South Africa's Electricity Supply Commission (ESKOM) became an important regional power supplier. After "the Firm Power Contract (FPC) with ESKOM expired in 2005 and could not be renewed due to a critical power shortage faced in South Africa at the time. . imports [for Namibia] became significantly more expensive, especially during peak hours" (NamPower, 2018).

It is against this backdrop that the Angolan and Namibian governments decided to go ahead and speed up the construction of Orokawe in 2014. The Baynes dam would not make sense without repair of the toll earlier hostilities had taken on the dams upstream in Angola, and it took until 2012 before a rehabilitation contract was signed for the Calueque dam, bombed by Cuban forces in 1988 (Meissner, 2016). In November 2014, Angolan and Namibian ministers met in Luanda, Angola's capital, to recommend to both governments to endorse the outcome of feasibility studies for the implementation of the Baynes Hydro Project. They furthermore decided to commence negotiations with the affected communities within the project area.

Even so, indigenous peoples have been voicing their opposition toward the Orokawe dam, employing several diplomatic efforts to sway the Namibian government not to construct the dam (Earth Peoples, 2018). In doing so, they repeated and refined several tactics developed to counter the plan's previous incarnation, the Epupa dam. Once they became aware of the Epupa dam project in the 1990s, indigenous peoples have successfully been voicing their opposition toward the dam, exploiting several diplomatic efforts to sway the Namibian government not to construct the dam (ERM Southern Africa, 2009; Meissner, 2016). This has, incidentally, not been mirrored by much engagement on the part of the Namibian government and the country's electricity utility NamPower. Moreover, NamPower's Orokawe dam internet page does not mention them, although the environmental, social, and health impact assessment report conducted by ERM Southern Africa in 2009 elaborately mentions the peoples' resignation toward the project. 


\section{Revival and diplomacy on the Orokawe dam project}

The search for alternatives to reduce dependence on South Africa in 2005 gave the Namibian government a big economic impetus to revive the Orokawe Hydropower Project, alternatively known as the Baynes Project after its location in the Baynes Mountains, and managed to enlist Angolan support for going ahead with the dam. A Brazilian consortium carried out a feasibility study and a new Environmental Impact Assessment was commissioned, tendered and awarded to British consultants ERM Southern Africa (2009), which again found in favor of the Baynes dam over Epupa, despite its smaller storage capacity, for being less environmentally intrusive and more culturally sensitive. This time, however, the Namibian government met with a well-oiled protest machinery. We will zoom in on how the indigenous peoples did this and may note that the Epupa protests have been a dress rehearsal.

In 2012, the OvaHimba, this time jointly with other local indigenous communities such as the OvaZemba (Tjimba), called on the United Nations, staged various protest rallies in Namibia in the same and following year, and signed public declarations against the construction of the Baynes dam (analysis to follow). This time, the Namibian government sought to respond, organizing a meeting in Windhoek in 2013 with three members of the Himba community. During the meeting "a 22-page report was handed out that states that an open-door approach would be pursued in which the communities would be consulted to avoid resettlement" (Earth Peoples, 2014). The OvaHimba resisted, claiming the door was not open and that they had repeatedly said "no." To increase the solution space, the OvaHimba also met with experts on solar energy during their Windhoek trip to explore it as an alternative in the same location. Like in their 2012 missive, they insisted they felt unheard and therefore refused to negotiate. This article will zoom in on the documents the indigenous drafted to further their cause.

\section{Analysis of indigenous paradiplomacy by dam-affected people}

The Orokawe Declaration is a handwritten document in English dated February 7,2012 . As the title states, numerous indigenous groups note their arguments against the Orokawe dam in this declaration. At the end of the document, most of the chiefs or senior councilors representing the various indigenous groups "signed" the document (Table 2) with a thumbprint. 
Table 2 - Signatories of the Orokawe Declaration

\begin{tabular}{ll}
\hline Individual that signed the declaration & Representing \\
\hline Chief Hikuminue Kapika & Epupa and Omuhonga \\
Chief Tjinae Tjingee & Otjikojo \\
Kambiriyere Kapika signed as Kapika & Elder from Omuhonga \\
Muhapika Munjombara signed as Mutabo & Senior Councilor, Epupa \\
Matumbuyani Kapika & Senior Councilor, Epupa \\
Yapimbiyapo Tyaombe & Senior Councilor, Omuhonga \\
Yararauke Tjingee & Senior Councilor, Omuhonga \\
Vatako Hembinda & Senior Councilor, Omuhoro \\
Vatundauka Ngumbi & Senior Councilor, Omuhonga \\
Mbasekama Ngombe & Senior Councilor, Omuhonga \\
Mbyangue Tjiposa & Senior Councilor, Okanguah \\
\hline
\end{tabular}

The original single author of the declaration is unknown- "single author" because the handwriting in the declaration is uniform throughout.

The OvaZemba Declaration is a typed document in English dated February 12, 2012, numbering six pages, and signed by numerous representatives of the OvaZemba, either in handwriting or with a thumbprint. ${ }^{4}$ The OvaHimba Declaration is similar to the OvaZemba Declaration and is a typed document in English dated January 20, 2012 numbering seven pages. The signatories, again thumb-printed, are all OvaHimba chiefs from several areas. All three declarations are directed toward the Namibian government and no mention is made of the Angolan government.

We analyzed the content of all three declarations to ascertain how the indigenous peoples apply the various forms of ideational power in their diplomacy efforts to persuade the Namibian government not to construct the Orokawe dam. We decided to investigate the text of these information sources because of their salience in expressing the indigenous peoples' aspirations against the large dam. That said, we did not analyze their ideational powers regarding other matters, such as land rights, schooling, and recognition of traditional leadership structures. While these are important, our focus is on indigenous paradiplomacy and the use of ideational powers in exercising such diplomacy. The following section will describe our analysis of the information sources by firstly describing the nature of each before discussing our content analysis applying Carstensen and Schmidt's (2016) conceptualization of ideational power. 
The aforementioned indigenous peoples have been voicing their opposition toward the dam utilizing several diplomatic efforts to sway the Namibian government, as well as the international community. For this reason, the indigenous peoples are invoking the United Nations Declaration on the Rights of Indigenous Peoples (UNDRIP) (UN, 2007) in the Orokawe Declaration, which, accordingly, forbids forcible displacement and insists on their informed assent. The declaration, furthermore, requests the UN Special Rapporteur on Indigenous Rights to review the case. It cites several UNDRIP articles in their arguments against the dam; articles $4,5,8,10,13,18,19,20,26,27,30,32,33,34$, and 38 (Declaration, 2012b). This indicates that the subaltern, the indigenous peoples, resort to international power fora, such as UNDRIP, to advance their argument against the dam. In this case, the UNDRIP articles act as background knowledge and specifically regarding the peoples' rights as "indigenous" citizens of Namibia. In an article discussing UNDRIP, Duane Champagne (2012) asks whether UNDRIP is an instrument of indigenous empowerment or a form of assimilation. It would appear as if the OvaHimba and OvaZemba utilizes it as a form of empowerment. However, Champagne (2012) notes that states do not view it as such since they ignore indigenous peoples' history and have incorporated them as citizens into the nation-state without consent. They are treated as part of a population, and as such, they do not have claims to self-government and territory. Because of this, UNDRIP, as a structure of rule, does not address indigenous political, cultural and territorial claims (Champagne, 2012). It would, therefore, appear as if the interpretation of UNDRIP's content is a type of ideational power blocking the indigenous peoples' territorial claims. Nevertheless, and since the indigenous peoples utilize UNDRIP, this suggests that the Declaration is one of many instruments in their indigenous paradiplomacy toolbox. In this regard, Nigel Crawhill (2011, p. 11) argues that UNDRIP's passing in 2007 came from a "global awareness of the need for more effective human rights mechanisms for non-dominant peoples." That said, ideational power does not have to be a mechanism to persuade the other actor to do what the intender wants it to do; with UNDRIP acting, in this regard, as a power through ideas instrument, as explained in Table 1.

Not only did the indigenous peoples invoke an international structure of rule to inform and strengthen their background knowledge of their rights as indigenous peoples, the OvaHimba Declaration reports a string of meetings with the Namibian government in which they, as original inhabitants and "true owners" of the area that was going to be "destroyed and flooded by the dam," emphatically refused the dam. The declaration mentions members being offered money by way of compensation, but dis- 
missed it out of hand: "If they are going to build the dam, they better first kill us before they do that" - some will drown themselves in the reservoir, but others will declare "civil war" (Declaration, 2012a).

Having said that, from our analysis of the three declarations, we find that the indigenous peoples are using predominantly the "power over ideas" mechanism of the ideational power typology, as explained in Table 1 , and specifically the types employed by normally powerless actors who want to shame others into conformity with their norms and ideas. The shaming is directed toward the Namibian government and come in various forms. In the Orokawe Declaration the peoples state that: "since independence, the Government has dispossessed us from our rights to our land, and our rights to decide what [sic] is being done with and on it. That is a direct violation of UNDRIP Article 4, 8(2b), 26, 27. Our traditional Leaders, our representatives that we choose, are not recognized by the Government of Namibia, violating again the ... UNDRIP, Article 4, 5, 18, $19,20,32,33,34,38$ "' (Declaration, 2012b). The shaming harks back to the days when SWAPO waged an armed liberation struggle against apartheid South Africa that controlled Namibia. Not only did SWAPO wage an armed struggle against South Africa, the liberation movement also utilized the United Nations to argue for Namibian independence from South Africa (Barber \& Barratt, 1990). Today SWAPO is the ruling party governing the Namibian state and government, and it would appear as if the indigenous peoples are trying to capitalize on the ruling party's history when it used international fora and declarations to advance Namibia's independence. On this, the indigenous peoples also remind the Namibian government, in the Orokawe Declaration, that the government had adopted the UN Declaration (Declaration, 2012b). We also see the "power over ideas" (Table 1) and shaming of the Namibian government in the OvaHimba Declaration when they say that: "We and other traditional leaders from other tribes went to the High Court, and we won the case on December 13th 2001, and the Government of Namibia was ordered to re-install us [traditional leaders] in our rightful positions as Traditional Authorities" (Declaration, 2012c). In these cases, we see the classic case of the blurred lines between domestic politics and international relations with the indigenous peoples utilizing ideational power elements from both domains.

We also noticed the use of "power through ideas" (explained in Table 1), where the indigenous peoples are using "technical and scientific" means to advance their argument against the Orokawe dam. In the Orokawe Declaration, they argue that should the dam be constructed, they "don't want an influx of strangers that will come with the construction of the dam. We don't want to face the negative impact that comes with such a large-scale 
construction i.e. tarred [sic] roads, large trucks, shops owned by strangers, foreign traders, big town, prostitution, theft, crime, diseases, and the loss and destruction of land. We don't want the river being blocked. Water is life. The fish, turtles and crocodiles will suffer. Some may die" (Declaration, 2012b). These issues were also raised in the OvaHimba Declaration when the traditional leaders wrote that they fear the spread of HIV/AIDS and other sexually transmitted diseases from migrant workers, "which would surely decimate ... our less 'civilized' communities" (Declaration, 2012c). In the past, the interest groups arguing against the construction of the Epupa dam, utilized "scientific" arguments as a basis for authoritative argumentation (Meissner, 2016) in contrast to the positive benefits being advocated by NamPower. The technical and scientific reasoning from the indigenous peoples highlights the various human, cultural, and environmental costs of the project, which is akin to the rational cost-benefit analysis of feasibility studies arguing for the construction of large dams. It is possible that the indigenous peoples learned of negative ecological impacts of large dams from interest groups during their campaign against the Epupa dam. During this campaign, international interest groups conducted an independent feasibility study of the dam wherein they decried the destructive impact of the dam on the aquatic fauna and flora (Harring, 2001; Meissner, 2016).

Speaking of feasibility studies, in the OvaHimba Declaration, the traditional leaders argue that they and the affected communities had not been consulted nor included in any of the planning steps and decision-making levels for the Orokawe dam (Declaration, 2012c). In the OvaZemba Declaration, the traditional leaders argue that the OvaZemba and OvaHimba do not benefit from the water and electricity from the Ruacana hydroelectric scheme. This declaration notes that: "These projects [Ruacana and Orokawe] are promoted as developments for the citizens of Namibia, but they are the opposite of development for us. These projects have been taking our peoples [sic] grazing land" (Declaration, 2012a). These are ethical issues raised by the indigenous peoples to highlight that they are not the recipients of any benefits from such infrastructural projects. They are also highlighting their marginalization through the use of ideas infused with ethical arguments as to why Orokawe should not be constructed.

\section{Discussion}

Non-state actors such as interest groups often use paradiplomacy to catapult them to the top of political agenda. This practice of indigenous 
paradiplomacy by indigenous peoples, acting as communal interest groups, is often done in concert with another actor that has the necessary background knowledge about political structures that favor the minority indigenous groups. In this case, Earth Peoples had the necessary know-how to assist the indigenous peoples of the Kaokoland in their arguments against the Orokawe dam. The political structure that provided much needed background knowledge about the plight of the peoples is UNDRIP. The Orokawe Declaration is replete with mentions of various UNDRIP articles and even quotes from it. The transnationalization of the Orokawe dam conflict created additional pressure on Namibian decision-makers. The indigenous peoples institutionalized themselves by using the arguments based on UNDRIP and made the issue of indigenous people's rights part of the Orokawe dam issue. It is here where the indigenous people's arguing against the Orokawe dam enhance their position in this particular security field. They do this by stating that the dam is posing threats to their human security (such as loss of grazing land and potential exposure to HIV/AIDS) and that the dam is a threat to their human rights as indigenous peoples. This is the so-called boomerang effect in action that came about using Earth People's background knowledge of UNDRIP and the subsequent argument based on UNDRIP's various articles. We can, therefore, conclude that the indigenous peoples had used ideational power consciously and habitually; consciously because they knew that UNDRIP's content could give them power over Namibia's idea to construct Orokawe and habitually because the peoples have been using transnational interest groups previously to argue against the suggested Epupa dam (Meissner, 2016). The indigenous peoples of Kaokoland are practicing indigenous paradiplomacy using ideational power types as well as forging alliances with another transnational interest group, Earth Peoples. Put differently, they practice indigenous paradiplomacy in the Kunene (context) through doings (alliance formation and declaration writing) and sayings (the content of the declarations).

The indigenous peoples and Earth Peoples mobilized each other as political actors as well as elements to advance their struggle via "power through ideas" (Table 1). The environment in which the peoples acted was simultaneously a scientific-debating with the NamPower-and political context, by invoking UNDRIP and using its principles to state their case to the Namibian government. In this regard, UNDRIP could be an object that connected the indigenous peoples in the Kunene River basin with Earth People's in their bid to halt the Orokawe dam. Not only did the indigenous peoples do so within and outside the Kunene River basin connected with the rest of Namibia, they also connected it back in time. They did so by re- 
minding the Namibian government in the Orokawe Declaration that they were opposed to the Epupa dam and they are, again, not supporting the construction of Orokawe.

The indigenous peoples managed to mobilize power through ideas (Table 1) when international opinion leaders, like Earth Peoples, sided with them in the "ideological dissemination" of their arguments against Orokawe. Notably, the "shaming of powerful actors into conformity by raising consciousness about issues" was a consequence of the skillful deployment of power over ideas (Table 1) and is challenging the authority of actors such as NamPower and the Namibian government. The indigenous peoples challenged "the authority of certain ideas in structuring thought at the expense of other ideas" and as such the reigning "concept of control." Here we see the employment of agential and structural concepts in action: agential through declaration writing and debating with the Namibian government; and structural by utilizing UNDRIP to its fullest extent in arguing against the dam. This happened through the "power in ideas" type of ideational power, as explained in Table 1. Even so, they did not manage to structurally alter hegemonic ideas of energy-based development for the country and region. That said, we did not set out to prove that this instance of indigenous paradiplomacy was successful, only that the indigenous peoples and Earth Peoples have employed an ideational power strategy that made people aware of their plight and transnational lobbying efforts against the dam and in the process could have made some NamPower policy makers "jittery" and emboldened other indigenous peoples across the globe.

\section{Conclusion}

In this article we reported on the use (practice) of ideational power by the indigenous peoples in the Kunene River basin arguing against the construction of the Orokawe dam. We found that they utilize "power over ideas" predominantly because they invoke UNDRIP in their water diplomacy endeavors. They also "scientifically" argue against the dam by stating that it would negatively influence their human security, in terms of potential exposure to sexually transmitted diseases and loss of grazing land, and that the construction of the dam would be in violation of their human rights. Indigenous opponents often oppose megaprojects because of the siting (e.g., on top of graves or important religious sites). These ancestral sites are thus elevated to life and death issues, over and above normal politics and cost-benefit calculations. This practice happens 
through the three ideational power types discussed in this article. Such ideational power play can be effective when groups actively coalesce with like-minded groups and use specialized background knowledge gained from the network to generate ideational power principles.

Richard holds a M.A. degree in Political Studies from the Rand Afrikaans University, Johannesburg, and a D.Phil. degree in International Politics from the University of Pretoria. He is an Associate Professor at the University of South Africa's Department of Political Sciences where he conducts research on international politics, water governance, water politics and water security at domestic and international levels. His main interests are interest group water politics and local and transboundary water governance.

Jeroen holds a M.Sc. degree in international relations from the University of Amsterdam and PhD in disaster studies from Wageningen University. He teaches, trains, and publishes on domestic and transboundary water conflict, participatory resource management, and governance issues at Wageningen University. His main research interests in the disaster studies domain are social resilience.

\section{NOTES}

1. www.earthpeoples.org. This site has since been discontinued.

2. We also searched Twitter for tweets relating to the issue of the Orokawe dam and the lobbying efforts by the two tribes, but were unable to find any.

3. This declaration was consulted at: http://earthpeoples.org/blog/?p=1061. Unfortunately, it is no longer active. The declaration was signed by representatives of the indigenous peoples on February 7, 2012 at Omuhonga in Namibia (see Annex).

4. Not only did the chief of the OvaZemba People of Namibia, Jonas Kanakemue Tjikulya sign the document, but also the spokesperson of the Traditional Council, Titus Kuuoko, and the head of the Women's Council, Mbwale Sara. 


\section{ANNEX}

DEclaration of tHE mOST AND DIREctLY AFFEcted

OVAHIMBA, OVATWA, OUATJIMBA, OVAZEMBA AGANST THE OROKAWE DAM IN THE BAYNES MOUNTAINS

February 7,2012

omuhonga

When Namibia wanted to build the Epupa Dam, we objected. Today, we objeot again, this time against the new plans of the Government of Namibia to build a dam, this time at Orokawe in our Baynes Mountains. We, the most directly alfected Indigenous Peoples say No! We made in several meetings between us and the Government our refusal also to this dam very clear. At the most important big meeting in Opacwo end of 2011 with high level governmental authorities we again made our collective objection very clear. We don't understand why we have to repeat our selves over and over again, and the Government of Namibia is not listening to us, and is confinuing to push for the conshruction of the dam without our consent. We collectively retused the money olfered to those communities and families that would have to relocate it the Government is going to becitol the dam they better kill us first before they do that. This is our land. We are the original inhabitants and true owners of the area that would be destroyed and flooded by the dam. But since independence, the Government has dispossessed us from our riahls to our land, and our rights to decide what 


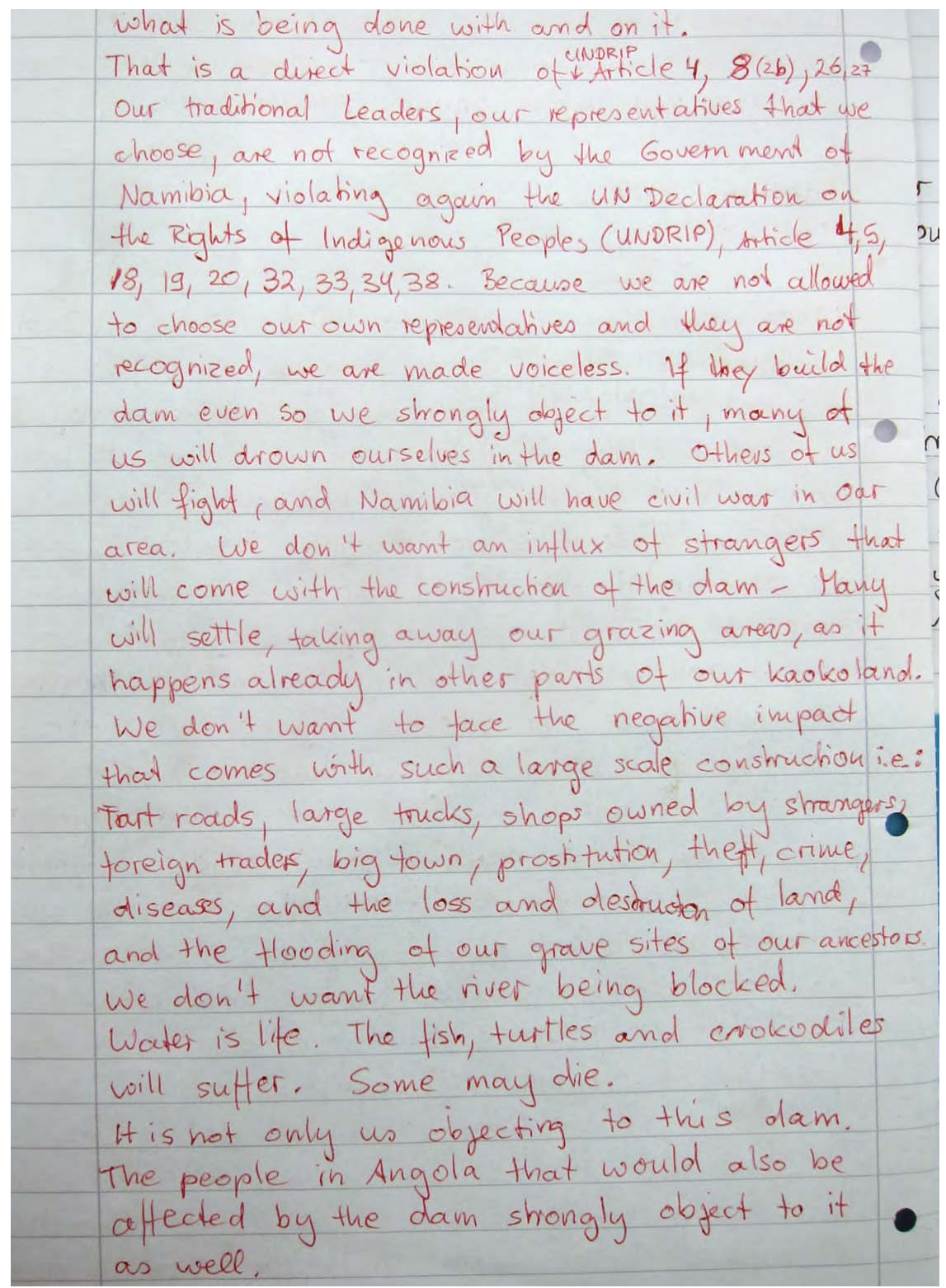




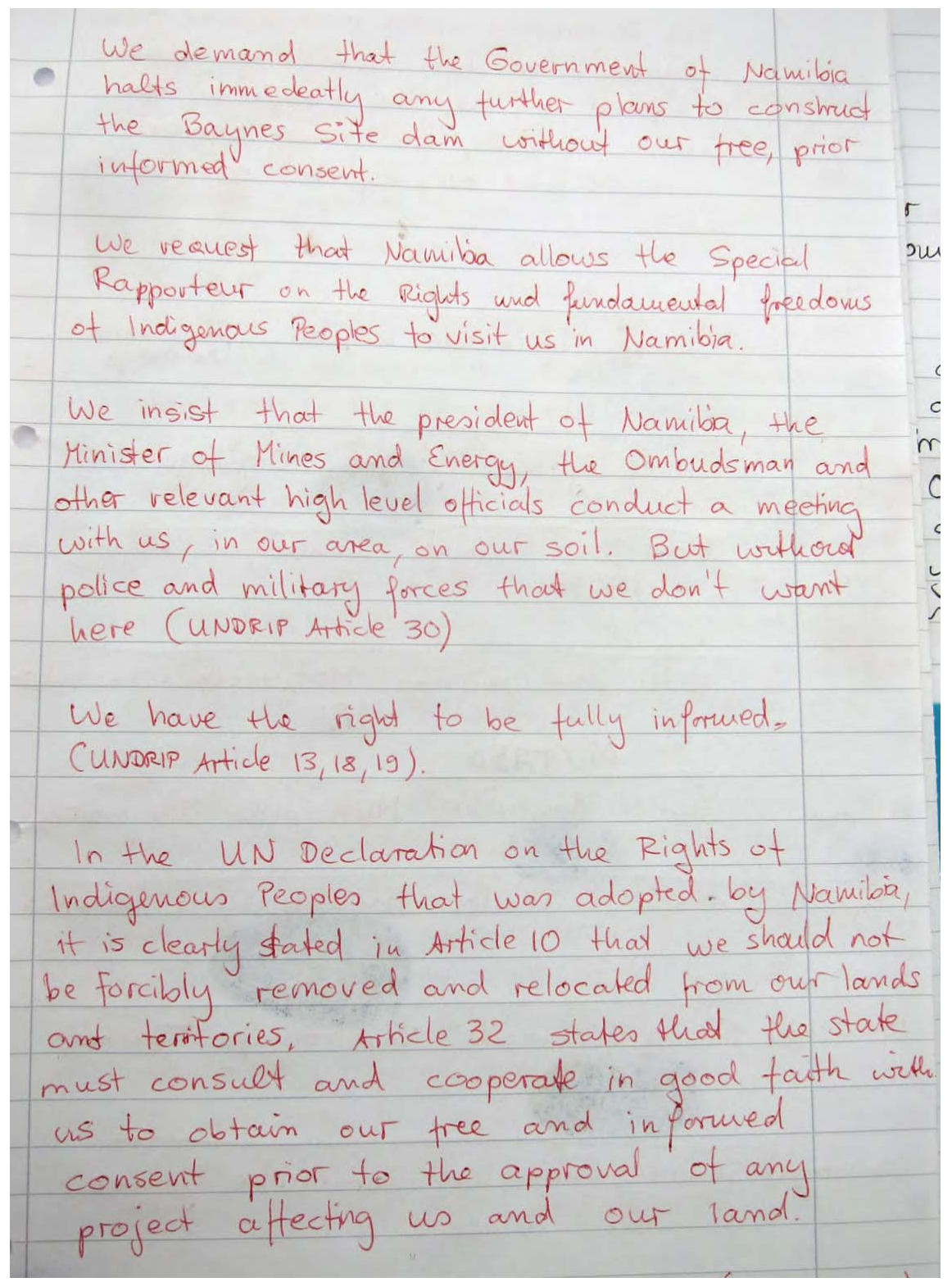




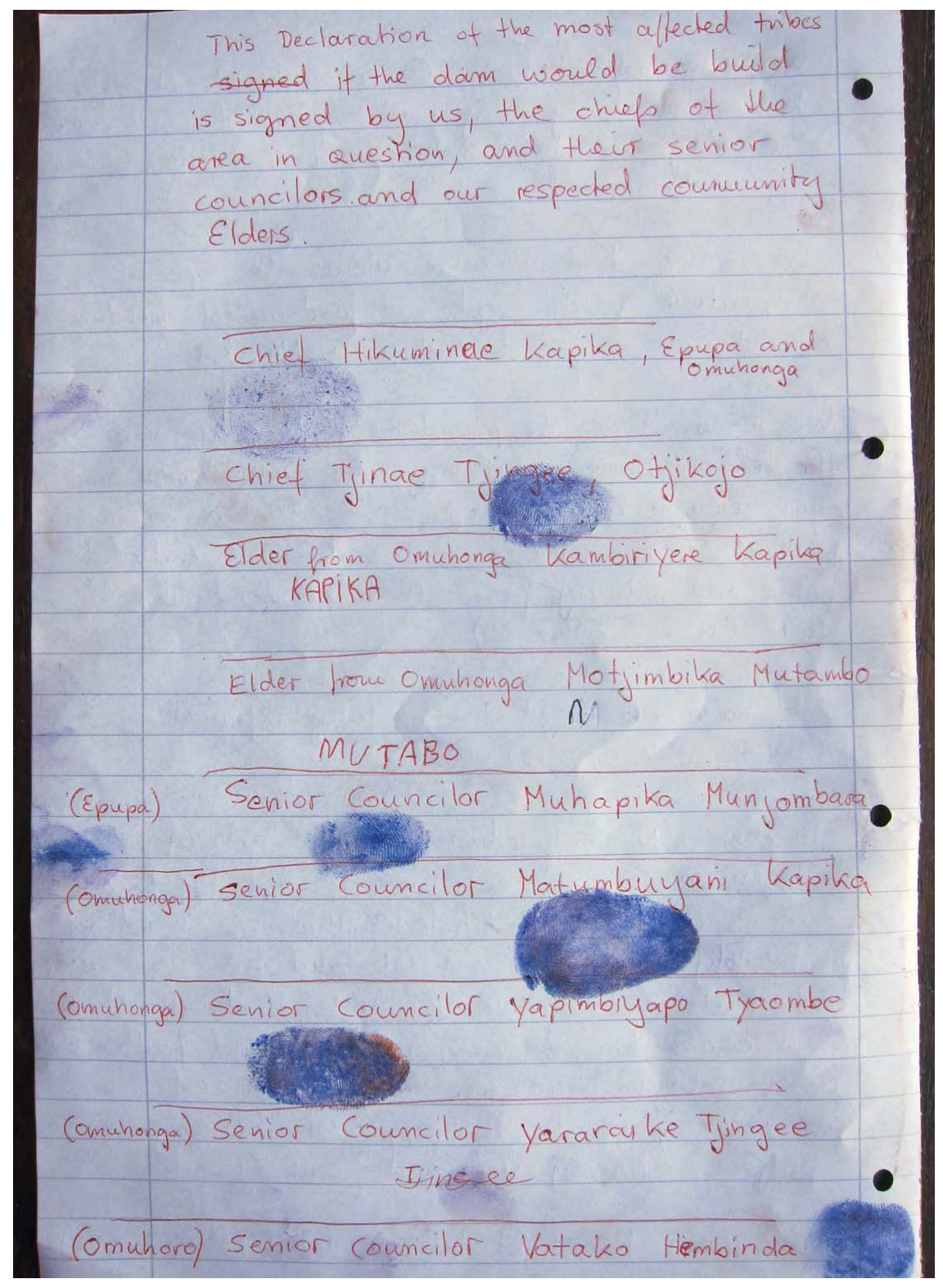




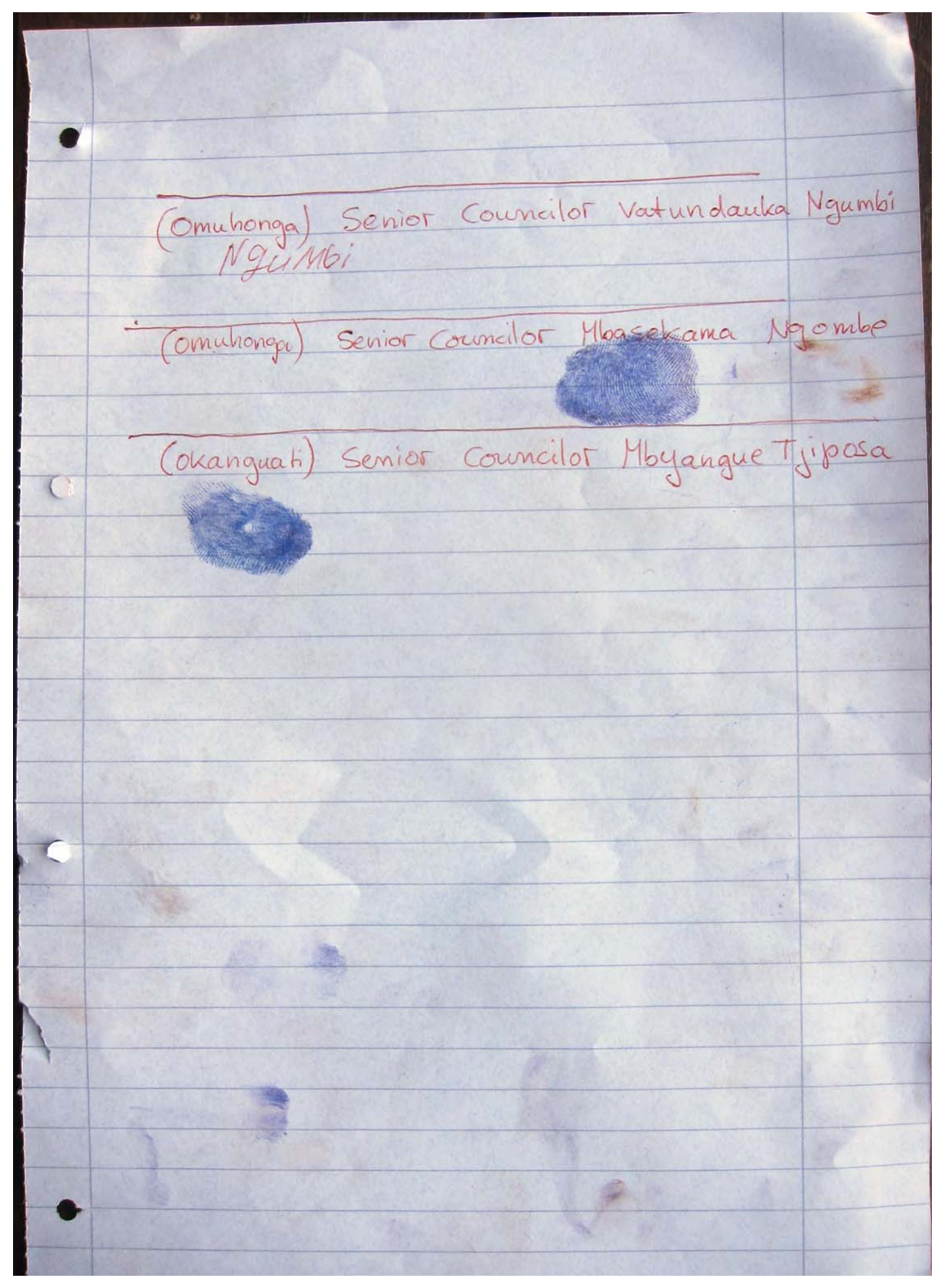




\section{REFERENCES}

Adler-Nissen, R., \& Pouliot, V. (2014). Power in practice: Negotiating the international intervention in Libya. European Journal of International Relations 20(4), 889-911.

Aranda, G., \& Salinas, S. (2017). Aymara paradiplomacy: power at the border. Estudios Fronterizos 18(35), 90-106. https://doi.org/10.21670/ref.2017.35.a05.

Barber, J., \& Barratt, J. (1990). South Africa's foreign policy: The search for status and security 1945-1988. Cambridge: Cambridge University Press.

Carstensen, M. B., \& Schmidt, V. A. (2016). Power through, over and in ideas: conceptualizing ideational power in discursive institutionalism. Journal of European Public Policy 23(3), 318-337. https://doi: 10.1080/13501763.2015.1115534.

Cascão, A. E., \& Zeitoun, M. (2010). Power, hegemony and critical hydropolitics. In A. Earle, A. Jägerskog, \& J. Öjendal (Eds), Transboundary water management: Principles and practice. (pp. 27-42) Milton Park, Abingdon: Earthscan.

Champagne, D. (2012). UNDRIP (United Nations Declaration on the Rights of Indigenous Peoples): Human, civil, and indigenous rights. Wicazo Sa Review 28(1), 9-22.

Cornago, N. (2010). Perforated sovereignties, agonistic pluralism and the durability of (Para)diplomacy. In C. M. Constantinou, \& J. Der Derian (Eds.), Sustainable diplomacies. (pp. 89-108) London: Palgrave Macmillan.

Crawhill, N. (2011). Africa and the UN Declaration on the Rights of Indigenous Peoples. The International Journal of Human Rights 15(1): 11-36. https://doi.org/ 10.1080/13642987.2011.529687.

Declaration. (2012b). Declaration of the most directly affected OvaHimba, OvaTwa, OvaTjimba, OvaZemba against the Orokawe dam in the Baynes Mountains: https:// rebeccasommer.wordpress.com/2012/02/07/declaration-of-the-most-directlyaffected-ovahimba-ovatwa-ovatjimba-and-ovazemba-against-the-orokawedam-in-the-baynes-mountains/ (Last retrieved 8 January, 2021)

Declaration. (2012c). Declaration of the Zemba people of Namibia. https://rebeccasom mer.wordpress.com/2012/02/12/declaration-of-the-zemba-people-of-namib ia-12-february-2012/. (Last retrieved 8 January, 2021)

Declaration. (2012d). Declaration of the most directly affected OvaHimba, OvaTwa, OvaTjimba, OvaZemba against the Orokawe dam in the Baynes Mountains. https:// rebeccasommer.wordpress.com/2012/02/07/declaration-of-the-most-directly-affected-ovahimba-ovatwa-ovatjimba-and-ovazemba-against-the-orokawedam-in-the-baynes-mountains/ (Last retrieved 8 January, 2021).

Earth Peoples. (2013). German GIZ directly engaged with dispossessing indigenous peoples of their lands and territories in Namibia. http://earthpeoples .org/blog/?tag=declaration-affected-ovahimba-ovatwa-ovatjimba-and-ovaze mba-orokawe-dam-baynes-mountains-namibia-africa-human-rights-violat ions-environment-mother-earth-himba-chiefs-leaders-indigenous-peoples.

Earth Peoples. (2014, 30 March). Information statement from Himba community Epupa, 3http://earthpeoples.org/blog/?cat=134.

Earth Peoples. (2018, 22 November). About us. http://earthpeoples.org/blog/?pa ge_id=2. 
ERM Southern Africa. (2009). Baynes hydropower environmental, social and health impact assessment (ESHIA): Final scoping report. Johannesburg: ERM Southern Africa.

Heyns, P. (2003). Water resources management in Southern Africa. In M. Nakayama (Ed.), International waters in Southern Africa. (pp. 5-37) Tokyo: United Nations University Press.

Harring, S. L. (2001). 'God gave us this land'. The OvaHimba, the proposed Epupa Dam, the independent Namibia state, and law and development in Africa. Georgetown International Environmental Law Review, 14(1), 35-106.

Islam, S., \& Repella, A. C. (2015). Water diplomacy: A negotiated approach to manage complex water problems. Journal of Contemporary Water Research and Education, 155, 1-10. https://doi.org/10.1111/j.1936-704X.2015.03190.x.

Meissner, R. (2016). Hydropolitics, interest groups and governance: The case of the proposed Epupa dam. Cham, Switzerland: Springer.

NamPower. (2018, 22 November). Baynes hydropower project. https://www.nam power.com.na/page.aspx? $\mathrm{p}=222$.

Nganje, F. I. (2014). Paradiplomacy and the democratisation of foreign policy in South Africa. South African Journal of International Affairs 21(1), 89-107. https:// doi.org/10.1080/10220461.2014.895082.

Reus-Smit, C. (2001). Human rights and the social construction of sovereignty. Review of International Studies 27, 519-538.

Sikkink, K., \& Keck, M. (1998). Activists beyond borders. Ithaca, NY: Cornell University Press.

SommerFilms. (2019, 19 September). Biography. http://www.sommerfilms.org/bi ography.html.

United Nations (UN). (2007). United Nations Declaration on the Rights of Indigenous Peoples. New York: United Nations. Resolution 61/295 adopted by the General Assembly, United Nations. https://www.un.org/esa/socdev/unpfii/ documents/DRIPS_en.pdf.

Warner, J. (2004). Plugging the GAP working with Buzan: the Ilisu dam as a security issue. Occasional Paper No 67, School of Oriental and African Studies, University of London.

\section{Paradiplomacia indígena y la presa hidroeléctrica Orokawe en el río Kunene}

\section{Richard Meissner, Jeroen Warner}

Resumen: ¿Qué papel desempeñan los no-diplomáticos en la gestión y modificación de las relaciones de poder en las cuencas fluviales transfronterizas? Respondemos investigando los esfuerzos de cabildeo de los pueblos indígenas para detener la construcción de la presa Orokawe (Baynes) en el río Kunene, entre Angola y Namibia. La asignación y gestión de este recurso hídrico transfronterizo, cuenta con varios tratados concluidos que establecen el contexto de la diplomacia estatal bilateral. La base teórica de esta investigación son las conceptualizaciones del poder ideacional y la "teoría de la práctica". El empleo del poder ideacional 
en ríos transfronterizos se refleja en prácticas como el cabildeo y el desarrollo de redes transnacionales. Este artículo sostiene que los actores practican conscientemente este poder durante la diplomacia del agua transfronteriza.

Palabras clave: cuenca transfronteriza, Namibia, OvaHimba, OvaZemba, paradiplomacia, poder ideacional

\section{La paradiplomatie indigène et le barrage hydroélectrique d'Orokawe sur le fleuve Kunene}

\section{Richard Meissner \& Jeroen Warner}

Resumé: Quel rôle les non-diplomates peuvent-ils jouer dans la gestion et la modification des relations de pouvoir dans les bassins fluviaux transfrontaliers? Nous répondons à cette question en enquêtant sur les efforts de lobbying des peuples autochtones pour arrêter la construction du projet du barrage d'Orokawe (Baynes) sur le fleuve Kunene. Le Kunene forme une partie de la frontière entre l'Angola et la Namibie, pays entre lesquels plusieurs traités sont en vigueur. Ces traités définissent le contexte de la diplomatie bilatérale des États concernant le partage et la gestion de la ressource en eau transfrontalière. Les fondements théoriques de notre enquête reposent sur les conceptualisations du pouvoir idéationnel et la théorie de la pratique. L'article aborde les nombreuses pratiques du pouvoir idéationnel dans les cours d'eau transfrontaliers, telles que le lobbying et le développement de réseaux transnationaux. Il soutient que les acteurs exercent consciemment le pouvoir dans le cadre de la diplomatie transfrontalière de l'eau.

Mots-clés: bassin transfrontalier, Namibia, OvaHimba, OvaZemba, paradiplomatie, pouvoir idéationnel. 